\title{
Leuk dat je als CEO de onderneming duurzaam wilt maken, maar niet ten koste van het rendement!
}

\author{
Mr.A.C. Jansen*
}

\begin{abstract}
Met het aangekondigde vertrek van Emmanuel Faber, CEO van Danone, hebben twee activistische aandeelhouders bun zin gekregen die het niet eens waren met de gekozen (duurzame) strategie. In deze column wordt betoogd dat het belangrijk is dat in de zoektocht naar een eventuele hervorming van het vennootschapsrecht om duurzaam ondernemen aan te moedigen, oog te hebben voor het gehéle systeem van corporate governance, en met name de uitwerking van eventuele nieuwe wettelijke regelingen in de praktijk.
\end{abstract}

Op 30 maart jl. kopte Het Financieele Dagblad 'Danone en het ongeduld van aandeelhouders', naar aanleiding van de val van Emmanuel Faber, $\mathrm{CEO}$ van de Franse beursgenoteerde zuivelgigant Danone. ${ }^{1}$ Net als Paul Polman van Unilever, Indra Nooyi van PepsiCo en Feike Sijbesma van DSM was Emmanuel Faber een van de meest vocale voorvechters van duurzaam ondernemen. ${ }^{2}$ Betekent de val van Faber het einde van het nieuwe kapitalisme waarin CEO's (durven te) streven naar een betere wereld?

Faber is in 2014 aangetreden als CEO van Danone en stond met name bekend om zijn sociale en ecologische oriëntatie. Vorig jaar zomer berichtte Faber nog met trots dat Danone de eerste onderneming was die op basis van wetgeving de titel 'Enterprise à Mission' - in het Nederlands vertaald als 'onderneming met een missie' - mocht voeren. ${ }^{3}$ Het Franse ondernemingsrecht voorziet namelijk sinds anderhalf jaar in de mogelijkheid om een 'raison d'etre', oftewel een bestaansgrond op te nemen in de statuten, om zo de verantwoordelijkheid van ondernemingen in de samenleving te versterken. ${ }^{4}$

\footnotetext{
Mr. A.C. Jansen is als PhD-fellow verbonden aan de Afdeling Ondernemingsrecht van de Universiteit Leiden. Zij schrijft een proefschrift over maatschappelijk verantwoord ondernemen.

1. 'Danone en het ongeduld van aandeelhouders', Het Financieele Dagblad 30 maart 2021.

2. Zie ook 'Danone en het ongeduld van aandeelhouders', Het Financieele Dagblad 30 maart 2021.

3. Persbericht van Danone, Shareholders unanimously vote for Danone to become the first listed 'Entreprise à Mission', 26 juni 2020, te raadplegen op www.danone.com/media/corporate-press-releases.html.

4. In Frankrijk wordt een dergelijke onderneming dan als een 'onderneming met een missie' aangeduid. Zie voor meer hierover J.M. de Jongh, Onderneming en maatschappij: naar een nieuw sociaal contract? De Loi PACTE als voorbeeld, Ondernemingsrecht 2020/80.
}

De gekozen bestaansgrond van Danone is 'Gezondheid door voedsel voor zo veel mogelijk mensen'. ${ }^{5}$ De beurskoers en het streven naar winst (op korte termijn) zijn dus niet per se leidend bij Danone.

En dat is precies waar Faber op is afgerekend. Waar Polman, Nooyi en Sijbesma als voorvechters van duurzaam ondernemen niet langer als CEO aan de betreffende beursgenoteerde vennootschappen verbonden waren, leek het erop dat Faber nog als een van de laatste (vocale) voorvechters van duurzaam ondernemen rechtovereind kon blijven staan. Maar met het gedwongen ontslag van Faber als CEO begin maart van dit jaar is ook hij van zijn spreekwoordelijke troon gestoten. Twee activistische aandeelhouders, het Britse investeringsfonds Bluebell Capital en het Amerikaanse investeringsfonds Artisan Partners, hebben sinds januari na een al langer tegenvallende beurskoers van Danone - zeker vergeleken met de betere beurskoersen van concurrenten als Nestlé en Unilever - de druk zodanig opgevoerd dat het aanblijven van Faber niet langer houdbaar was. De boodschap van de aandeelhouders was helder: leuk dat je als CEO de onderneming duurzaam wilt maken, maar niet ten koste van het rendement.

Bestuurders (en commissarissen) verkeren daarmee - ook in Nederland - in een spagaat. Aan de ene kant moeten zij steeds op hun hoede zijn voor activistische aandeelhouders die met een Angelsaksische benadering eisen dat op korte termijn rendementen worden behaald. ${ }^{6}$ Aan de andere kant moeten bestuurders en commissarissen rekening houden met de verwachtingen vanuit de samenleving en de overheid, werknemers, klanten en andere stakeholders als het om duurzaam ondernemen gaat. Zeker de jongere (nieuwe) generatie vindt het belangrijk dat ondernemingen duurzaam handelen, of sterker nog, wil zich alleen nog maar aansluiten bij of associëren met ondernemingen die zich verantwoordelijk voelen voor de

5. Zie www.danone.com/about-danone/sustainable-value-creation/dano ne-entreprise-a-mission.html, laatst geraadpleegd op 2 mei 2021.

6. De aandeelhouders hebben immers invloed op het benoemen en het ontslag van bestuurders (zie art. 2:132 lid 1, 2:242 lid 1, 2:134 lid 1 en 2:244 lid 1 BW). 


\section{Maandblad}

toekomstige generaties. ${ }^{7}$ En dit moet allemaal gebeuren binnen de grenzen van langetermijnwaardecreatie om überhaupt als onderneming een blijvend bestaansrecht te hebben. Bestuurders (en commissarissen) kunnen daarin niet iedereen tevreden houden en zullen keuzes moeten maken. Het is vaak óf investeren in duurzaamheid om de samenleving tevreden te stellen óf het doen van winstuitkeringen om activistische aandeelhouders met een kortetermijnvisie tevreden te stellen.

We staan voor een grote uitdaging in het vennootschapsrecht. Het is de vraag in hoeverre het huidige vennootschapsrecht bestuurders (en commissarissen) voldoende ruimte biedt om duurzame ambities te hebben, en daarmee of het vennootschapsrecht nog wel bestand is tegen het nieuwe fenomeen duurzaam ondernemen. Wat dat betreft komt het ontslag van Faber op een bijzonder (goed) moment. Dit voorval laat zien dat, in de zoektocht naar een eventuele hervorming van het vennootschapsrecht, het belangrijk is oog te hebben voor het gehéle systeem van corporate governance. Daarbij dient vooral ook het praktische oogpunt niet verloren te gaan. Hoewel er veel aandacht is voor maatschappelijk verantwoord ondernemen, wordt naar de uitvoering in de praktijk (vooralsnog) nauwelijks gekeken. Het invoeren van een wettelijke zorgplicht voor bestuurders (en commissarissen), waarvoor bijvoorbeeld wordt gepleit, kan ervoor zorgen dat veel meer bestuurders (en commissarissen) worden aangemoedigd om duurzaam te gaan ondernemen, maar is dat dan wel voldoende? ${ }^{8}$ Grijpen activistische aandeelhouders met een kortetermijnvisie niet alsnog hun kans om bestuurders en commissarissen uit de weg te ruimen? Als we dit soort vroegtijdige ontslagen willen voorkomen en duurzaam ondernemen echt op de kaart willen zetten, dan moeten we hier iets mee. Verlies hierbij dan het gehele systeem van corporate governance, en met name de uitwerking van eventuele nieuwe wettelijke regelingen in de praktijk, niet uit het oog. Het zijn uiteindelijk de ondernemingen - en daarmee met name de bestuurders (en commissarissen) - die het moeten doen.

7. Zie in bevestigende zin: 'The Authenticity Gap Report 2017' van het communicatiebureau FleshmanHillard Fishbrun, te raadplegen op https://fleishmanhillard.co.uk/2017/07/authenticity-gap-

report-2017/, laatst geraadpleegd op 2 mei 2021, en 'The 2016 Deloitte Millennial Survey. Winning over the next generation of leaders', te raadplegen op www2.deloitte.com/content/dam/Deloitte/global/ Documents/About-Deloitte/gx-millenial-survey-2016-exec-summary. pdf, laatst geraadpleegd op 2 mei 2021.

8. J.W. Winter e.a., Naar een zorgplicht voor bestuurders en commissarissen tot verantwoorde deelname aan het maatschappelijk verkeer, Ondernemingsrecht 2020/86, p. 471 e.v. 